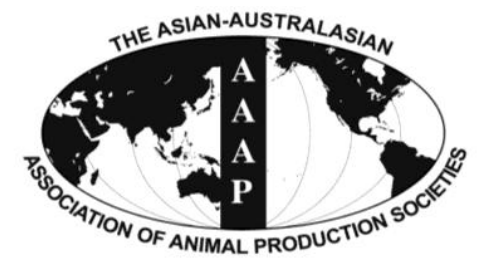

Asian-Aust. J. Anim. Sci.

Vol. 25, No. 6 : 880 - 885

June 2012

www.ajas.info

http://dx.doi.org/10.5713/ajas.2011.11521

\title{
Dietary Carob Pods on Growth Performance and Meat Quality of Fattening Pigs
}

\author{
Nikolaos Kotrotsios ${ }^{1}$, Efterpi Christaki*, Eleftherios Bonos ${ }^{2}$ and Panagiota Florou-Paneri \\ Laboratory of Nutrition, Faculty of Veterinary Medicine, Aristotle University of Thessaloniki, \\ 54124, Thessaloniki, Greece
}

\begin{abstract}
In this experiment the effect of dietary carob pods in the growth performance of fattening pigs and their meat quality, including steak chemical composition and fatty acid profile, were examined. A total of 160 weaning piglets, 30 days old, were allocated into four equal groups with 4 subgroups of 5 female and 5 males each. The animals were fed with isocaloric and isonitrogenous diets, containing either 0 or 75 or 100 or $125 \mathrm{~g}$ of carob pods per $\mathrm{kg}$ of feed. At the end of the experiment, on the 180 day of age, carcass subcutaneous fat thickness, steak chemical composition and steak fatty acid profile were determined. The results of the experiment showed that the dietary addition of 75 or $100 \mathrm{~g} / \mathrm{kg}$ carob pods increased body weight at slaughter and carcass weight. No significant effect was noticed on the other examined carcass parameters. Consequently, carob pods could be suggested as a potential feed for fattening pigs without any adverse effect on their meat quality. (Key Words: Carob Pods, Pigs, Meat Quality, Carcass Composition, Fatty Acids)
\end{abstract}

\section{INTRODUCTION}

Carob tree (Ceratonia siliqua L.) is native to the Mediterranean area, but is also grown in some regions of the USA, Latin America and Australia (Custodio et al., 2011). Worldwide, the main producers of carob fruits are Spain, Italy, Portugal, Morocco and Greece (FAO, 2009).

Traditionally, carobs were cultivated for human and animal nutrition, while nowadays carob seeds and pods have a wide application in the food industry as natural food additives, e.g. as thickener and stabilizer agents, in industrial products such as cocoa substitute, gums, sugars, beverages or pharmaceutical and cosmetic industries (Barracosa et al., 2007; Tous et al., 2009).

Carob pods, which represent about $90 \%$ of the fruit weight, are a very good source of sugars (48 to 56\%) and gross energy, making them a high energy feed for animal nutrition. However, the addition of carob pods in animal

\footnotetext{
* Corresponding Author: Efterpi Christaki. Tel: +30-2310 999973, Fax: +30-2310 999984, E-mail: efchris@ vet.auth.gr

${ }^{1}$ Diakou 15, 43100, Karditsa, Greece.

2 Animal Production, Faculty of Technology of Agronomics, Technological Educational Institute of Western Macedonia, 53100, Florina, Greece.

Submitted Dec. 30, 2011; Accepted Mar. 23, 2012; Revised Mar. 28, 2012
}

diets should be limited due to their relatively high content of tannins (38\%), but low content of proteins ( 3 to $4 \%$ ) and lipids (0.4 to $0.8 \%$ ) (Albanell et al., 1991; Karabulut et al., 2006; Silanikove et al., 2006; Mohamed et al., 2008). Tannins are natural polyphenolic compounds of relatively high molecular weight, having the ability to form insoluble complexes with proteins and digestive enzymes, as well as carbohydrates (Biagi et al., 2010), resulting in the reduction of nutrients digestibility (Kotrotsios et al., 2010). Nevertheless, the presence of tannins in carob pods may have beneficial effects on human and animal health, due to their other properties, such as antidiarrheal, antibacterial, antioxidant and free-radical scavenging and antiproliferative activity in liver cells (Biagi et al., 2010; Custodio et al., 2011).

Carob pods have been used in animal nutrition, in diets of sheep (Karabulut et al., 2006), lamps (Priolo et al., 1998), rabbits (Gasmi-Boubaker et al., 2008), poultry (Sahle et al., 1992; Ortiz et al., 2004). Regarding pig nutrition, carob pods have been examined mainly in piglets (Lizardo et al., 2002; Andres-Elias et al., 2007; Biagi et al., 2010).

The aim of this study was to investigate the effect of dietary carob pods in the growth performance of fattening pigs and their meat quality, including steak chemical composition and fatty acid profile. 


\section{MATERIAL AND METHODS}

\section{Animals}

The experiment was performed in a commercial pig farm in Greece with a capacity of 200 sows. A total of 160 weaning piglets (Seghers males $\times$ Whiterock females), 30 days old, were divided into four equal groups (A, B, C, D) with four subgroups of 5 males and 5 females each. Each subgroup was housed in a flat-deck unit until the age of 8 weeks and then the pigs were moved into the stable units until the end of the trial. The whole experiment had 150 days duration and was performed under commercial conditions, according to the guidelines of the Greek Directorate General of Veterinary Services. All pigs were vaccinated against Aujesky disease virus, enzootic pneumonia and swine influenza virus.

\section{Diets}

Carob pods of Greek origin were used in this experiment. Their chemical composition was determined according to AOAC (2005), as follows: $897.7 \mathrm{~g} / \mathrm{kg}$ dry matter (DM), $44.1 \mathrm{~g} / \mathrm{kg}$ crude protein (CP), $2.4 \mathrm{~g} / \mathrm{kg}$ ether extract (EE), $79.8 \mathrm{~g} / \mathrm{kg}$ crude fibre (CF) and $30.0 \mathrm{~g} / \mathrm{kg}$ ash (AS). Moreover, it was determined that the carob pods had $48.9 \mathrm{~g} / \mathrm{kg}$ total phenolic compounds and $35.1 \mathrm{~g} / \mathrm{kg}$ total tannins (expressed as tannic acid equivalent), using the Folin-Ciocalteu method (Makkar, 2003). The condensed tannins content was determined $9.7 \mathrm{~g} / \mathrm{kg}$ (expressed as leukocyanidine equivalent) (Porter, 1989).

To meet the nutrient requirements of pigs (NRC, 1998) for each of the growth periods - weaning, growing, fattening - four isocaloric and isonitrogenous diets were formulated to contain $0 \mathrm{~g} / \mathrm{kg}, 75 \mathrm{~g} / \mathrm{kg}, 100 \mathrm{~g} / \mathrm{kg}$ and 125 $\mathrm{g} / \mathrm{kg}$ carob pods, and were offered to the pigs of groups A, $\mathrm{B}, \mathrm{C}$ and $\mathrm{D}$, respectively. These diets were based on maize, barley and soybean meal and were given to the animals in mash form. The diets were analyzed according to AOAC (2005) for DM, CP, EE, CF and AS. The metabolisable energy (ME) content $(\mathrm{kcal} / \mathrm{kg})$ was calculated from the feed ingredients. The ingredients and composition of these diets is presented in Table 1. Feed and drinking water were offered to the animals ad libitum, and feed consumption was recorded daily.

\section{Measurements}

All animals were individually weighted at days 85,115 and 180 of age. Feed conversion ratio (FCR) was calculated as "kg feed/kg weight gain" for ages 30 to 85,85 to 115 , and 115 to 180 .

At the end of the experiment all pigs were slaughtered in a commercial slaughter house. For each animal carcass weight was recorded and carcass dressing percentage (carcass weight/body weight) was calculated.

In 8 carcasses from each group (1 male and 1 female from each subgroup) the thickness of subcutaneous fat at the 13th rib and the 6th to 7th lumbar vertebrae were

Table 1. Ingredients and chemical composition of the weaning, grower and finisher experimental diets

\begin{tabular}{|c|c|c|c|c|c|c|c|c|c|c|c|c|}
\hline \multirow{2}{*}{ Ingredients $(\mathrm{g} / \mathrm{kg})$} & \multicolumn{4}{|c|}{ Weaning diet } & \multicolumn{4}{|c|}{ Grower diet } & \multicolumn{4}{|c|}{ Finisher diet } \\
\hline & $\mathrm{A}$ & $\mathrm{B}$ & $\mathrm{C}$ & $\mathrm{D}$ & $\mathrm{A}$ & $\mathrm{B}$ & $\mathrm{C}$ & $\mathrm{D}$ & $\mathrm{A}$ & $\mathrm{B}$ & $\mathrm{C}$ & $\mathrm{D}$ \\
\hline Maize & 581.2 & 493.5 & 465.5 & 429.0 & 361.0 & 299.9 & 290.0 & 280.2 & 380 & 323 & 313 & 303 \\
\hline Barley & 90 & 90 & 90 & 90 & 309 & 309 & 309 & 309 & 300 & 300 & 300 & 300 \\
\hline Soyabean meal, CP $44 \%$ & 260 & 270 & 272 & 276 & 200 & 199 & 205.2 & 211.3 & 180 & 190 & 195 & 200 \\
\hline Carob pods & - & 75 & 100 & 125 & - & 75 & 100 & 125 & - & 75 & 100 & 125 \\
\hline Vitamin+mineral premix & 40 & 40 & 40 & 40 & 30 & 30 & 30 & 30 & 30 & 30 & 30 & 30 \\
\hline Milk powder & 25 & 25 & 25 & 25 & - & - & - & - & - & - & - & - \\
\hline Acidifier & 2 & 2 & 2 & 2 & - & - & - & - & - & - & - & - \\
\hline Vegetable fat & 1.8 & 4.5 & 5.5 & 13 & 10 & 12 & 12 & 12 & 10 & 12 & 12 & 12 \\
\hline Wheat bran & - & - & - & - & 90 & 75.1 & 53.8 & 32.5 & 100 & 70 & 50 & 30 \\
\hline Total & 1,000 & 1,000 & 1,000 & 1,000 & 1,000 & 1,000 & 1,000 & 1,000 & 1,000 & 1,000 & 1,000 & 1,000 \\
\hline \multicolumn{13}{|l|}{ Analyzed composition (g/kg) } \\
\hline Dry matter & 878 & 877 & 877 & 878 & 878 & 877 & 877 & 876 & 877 & 877 & 876 & 876 \\
\hline Crude protein & 180.2 & 180.8 & 180.6 & 180.5 & 160.6 & 160.0 & 160.4 & 160.3 & 153.2 & 153.9 & 153.5 & 153.0 \\
\hline Ether extract & 30.8 & 32.0 & 32.5 & 38.3 & 36.6 & 37.3 & 36.7 & 36.2 & 37.2 & 37.7 & 37.2 & 36.7 \\
\hline Crude fiber & 36.8 & 43.6 & 45.8 & 48.0 & 47.3 & 50.3 & 50.4 & 50.5 & 47.1 & 49.3 & 49.5 & 49.6 \\
\hline Ash & 54 & 55 & 55 & 55 & 55 & 53 & 53 & 55 & 55 & 55 & 55 & 55 \\
\hline \multicolumn{13}{|l|}{ Calculated composition $(\mathrm{g} / \mathrm{kg})$} \\
\hline Calcium & 9.0 & 9.0 & 9.0 & 9.0 & 8.5 & 8.5 & 8.5 & 8.5 & 8.0 & 8.0 & 8.0 & 8.0 \\
\hline Total phosphorus & 7.0 & 7.0 & 7.0 & 7.0 & 6.5 & 6.5 & 6.5 & 6.5 & 6.0 & 6.0 & 6.0 & 6.0 \\
\hline Lysine & 12.7 & 12.7 & 12.7 & 12.7 & 10.0 & 10.0 & 10.0 & 10.0 & 9.0 & 9.0 & 9.0 & 9.0 \\
\hline Methionine and cystine & 7.4 & 7.4 & 7.4 & 7.4 & 5.5 & 5.5 & 5.5 & 5.5 & 6.0 & 6.0 & 6.0 & 6.0 \\
\hline Threonine & 7.5 & 7.5 & 7.5 & 7.5 & 7.3 & 7.3 & 7.3 & 7.3 & 5.7 & 5.7 & 5.7 & 5.7 \\
\hline Tryptophane & 2.6 & 2.6 & 2.6 & 2.6 & 2.1 & 2.1 & 2.1 & 2.1 & 2.0 & 2.0 & 2.0 & 2.0 \\
\hline Metabolizable energy $(\mathrm{kcal} / \mathrm{kg})$ & 3,200 & 3,200 & 3,200 & 3,200 & 3,050 & 3,050 & 3,050 & 3,050 & 2,900 & 2,900 & 2,900 & 2,900 \\
\hline
\end{tabular}


Table 2. Effect of dietary carob pods on pig body weight and feed conversion ratio (Mean \pm SD)

\begin{tabular}{|c|c|c|c|c|}
\hline & A & B & $\mathrm{C}$ & $\mathrm{D}$ \\
\hline Age (d) & \multicolumn{4}{|c|}{------------------------------------- Body weight of groups (kg) -------------------------------- } \\
\hline 85 & $28.7 \pm 5.97$ & $29.51 \pm 6.54$ & $31.08 \pm 6.13$ & $27.72 \pm 7.05$ \\
\hline 115 & $51.24 \pm 9.61$ & $51.90 \pm 10.96$ & $54.03 \pm 9.20$ & $49.47 \pm 11.45$ \\
\hline 180 & $110.89^{\mathrm{a}} \pm 11.77$ & $113.21^{\mathrm{b}} \pm 14.93$ & $115.00^{\mathrm{b}} \pm 12.11$ & $106.85^{\mathrm{a}} \pm 13.63$ \\
\hline Rearing period & \multicolumn{4}{|c|}{----- Feed conversion ratio of groups --- } \\
\hline Day 30 to 85 & $2.03 \pm 0.09$ & $2.05 \pm 0.07$ & $2.08 \pm 0.09$ & $2.17 \pm 0.07$ \\
\hline Day 85 to 115 & $2.44 \pm 0.20$ & $2.53 \pm 0.08$ & $2.56 \pm 0.23$ & $2.51 \pm 0.14$ \\
\hline Day 115 to 180 & $3.18 \pm 0.30$ & $3.28 \pm 0.30$ & $3.32 \pm 0.34$ & $3.38 \pm 0.28$ \\
\hline
\end{tabular}

Groups: $\mathrm{A}=0 \mathrm{~g}$ carob pods $/ \mathrm{kg}$ feed; $\mathrm{B}=75 \mathrm{~g}$ carob pods $/ \mathrm{kg}$ feed; $\mathrm{C}=100 \mathrm{~g}$ carob pods $/ \mathrm{kg}$ feed; $\mathrm{D}=125 \mathrm{~g}$ carob pods $/ \mathrm{kg}$ feed.

Means in the same row with different superscript differ significantly $(\mathrm{p}<0.05)$.

measured with an electronic caliper (Electronic Digital Caliper, EMC, China). Afterwards, from these carcasses the steak of the 13th rib was removed, sealed in a plastic bag and frozen at $-20^{\circ} \mathrm{C}$ for further analysis. These steaks were later analyzed according to the guidelines of AOAC (2005) for AS, EE, CP and moisture (MO). Moreover, the fatty acid composition of these steaks was determined according to AOAC (2005) with a gas chromatographic system (TraceGC model K07332, ThermoFinnigan, ThermoQuest, Milan, Italy).

\section{Statistical analysis}

The statistical analysis was performed using the SPSS 16.0.1 statistical package (SPSS Inc., Chigaco, IL, USA). The one-way analysis of variance for the four groups of the experiment was performed. Furthermore, regression analysis of the dietary carob pods inclusion effect was performed using the curve estimation function of SPSS. A value of $\mathrm{p} \leq 0.050$ was considered significant. Levene's test was applied to test the homogeneity of the variances. Duncan's test was applied to determine statistical differences between the means.

\section{RESULTS}

Table 2 presents the body weight and feed conversion ratio for the weaning, growing and fattening periods of pigs. No significant differences ( $p>0.05)$ were noticed in the body weight on days 85 and 115 . In the last measurement on day 180 of age it was found that groups B and C had significantly $(\mathrm{p}<0.050)$ higher body weight, compared to groups $\mathrm{A}$ and $\mathrm{D}$. Regarding the FCR, no significant differences $(p>0.05)$ were noticed in any period of age. Also, mortality did not differ significantly $(p>0.05)$ between the groups.

Dietary carob pods effect on pig carcass weight, carcass dressing percentage, and subcutaneous fat of the 13th rib and the 6th to 7th lumbar vertebrae is given in Table 3 . Carcass weight was significantly $(\mathrm{p}<0.050)$ higher, in groups $\mathrm{B}$ and $\mathrm{C}$ compared to groups $\mathrm{A}$ and $\mathrm{D}$, but no differences $(p>0.05)$ were found for the other parameters.

The results concerning the 13th rib steak chemical composition are shown in Table 4 . No significant $(\mathrm{p}>0.05)$

Table 3. Effect of dietary carob pods on pig carcass weight, carcass dressing percentage, and subcutaneous fat of the 13th rib and the 6th to 7 th lumbar vertebrae (Mean \pm SD)

\begin{tabular}{|c|c|c|c|c|}
\hline & $\mathrm{A}$ & B & $\mathrm{C}$ & $\mathrm{D}$ \\
\hline Carcass weight (kg) & $66.90^{\mathrm{a}} \pm 6.94$ & $68.28^{\mathrm{b}} \pm 9.41$ & $69.43^{\mathrm{b}} \pm 7.63$ & $64.30^{\mathrm{a}} \pm 9.35$ \\
\hline Carcass dressing $(\%)$ & $60.36 \pm 2.62$ & $60.32 \pm 3.30$ & $60.38 \pm 3.10$ & $60.06 \pm 2.77$ \\
\hline Subcutaneous fat of 13 th rib (mm) & $16.82 \pm 2.13$ & $16.87 \pm 2.95$ & $16.35 \pm 3.98$ & $15.56 \pm 3.81$ \\
\hline Subcutaneous fat of 6 th to 7 th lumbar vertebrae (mm) & $23.75 \pm 4.80$ & $23.38 \pm 4.65$ & $20.53 \pm 4.37$ & $27.81 \pm 4.52$ \\
\hline
\end{tabular}

Groups: $\mathrm{A}=0 \mathrm{~g}$ carob pods/kg feed; $\mathrm{B}=75 \mathrm{~g}$ carob pods $/ \mathrm{kg}$ feed; $\mathrm{C}=100 \mathrm{~g}$ carob pods/kg feed; $\mathrm{D}=125 \mathrm{~g}$ carob pods/kg feed.

Means in the same row with different superscript differ significantly $(\mathrm{p}<0.05)$.

Table 4. Effect of dietary carob pods on the chemical composition of the 13 th rib steak of the pigs (Mean \pm SD)

\begin{tabular}{lccc}
\hline & A & B & C \\
\hline Ash $(\mathrm{g} / \mathrm{kg})$ & $8.9 \pm 0.8$ & $9.3 \pm 0.7$ & $9.1 \pm 0.6$ \\
Ether extract $(\mathrm{g} / \mathrm{kg})$ & $157.6 \pm 73.3$ & $128.6 \pm 58.2$ & $131.2 \pm 56.7$ \\
Crude protein $(\mathrm{g} / \mathrm{kg})$ & $200.7 \pm 35.6$ & $211.3 \pm 41.6$ & $196.4 \pm 29.0$ \\
Moisture $(\mathrm{g} / \mathrm{kg})$ & $632.8 \pm 51.0$ & $651.6 \pm 27.4$ & $663.3 \pm 39.1$ \\
\hline
\end{tabular}

Groups: $\mathrm{A}=0 \mathrm{~g}$ carob pods/kg feed; $\mathrm{B}=75 \mathrm{~g}$ carob pods $/ \mathrm{kg}$ feed; $\mathrm{C}=100 \mathrm{~g}$ carob pods/kg feed; $\mathrm{D}=125 \mathrm{~g}$ carob pods/kg feed.

Groups did not differ significantly ( $\mathrm{p}>0.05)$. 
Table 5. Effect of dietary carob pods on the fatty acid composition ( $\mathrm{g} / 100 \mathrm{~g}$ fatty acids) of the 13 th rib steak of the pigs (Mean \pm SD)

\begin{tabular}{|c|c|c|c|c|}
\hline Fatty acids & $\mathrm{A}$ & $\mathrm{B}$ & $\mathrm{C}$ & $\mathrm{D}$ \\
\hline C10:0 & $0.09 \pm 0.02$ & $0.12 \pm 0.05$ & $0.09 \pm 0.06$ & $0.13 \pm 0.04$ \\
\hline $\mathrm{C} 12: 0$ & $0.13 \pm 0.04$ & $0.12 \pm 0.03$ & $0.16 \pm 0.12$ & $0.11 \pm 0.02$ \\
\hline $\mathrm{C} 14: 0$ & $1.65 \pm 0.10$ & $1.55 \pm 0.14$ & $1.76 \pm 0.38$ & $1.52 \pm 0.12$ \\
\hline $\mathrm{C} 14: 1$ & $0.01 \pm 0.01$ & $0.02 \pm 0.01$ & $0.02 \pm 0.01$ & $0.03 \pm 0.03$ \\
\hline C15:0 & $0.02 \pm 0.01$ & $0.05 \pm 0.03$ & $0.03 \pm 0.02$ & $0.03 \pm 0.01$ \\
\hline C15:1 & $0.04 \pm 0.03$ & $0.05 \pm 0.03$ & $0.05 \pm 0.02$ & $0.05 \pm 0.03$ \\
\hline $\mathrm{C} 16: 0$ & $27.36 \pm 2.17$ & $25.41 \pm 0.75$ & $26.47 \pm 2.26$ & $25.64 \pm 1.39$ \\
\hline $\mathrm{C} 16: 1$ trans & $0.34 \pm 0.07$ & $0.38 \pm 0.05$ & $0.38 \pm 0.04$ & $0.32 \pm 0.04$ \\
\hline $\mathrm{C} 16: 1 \mathrm{cis}$ & $2.21 \pm 0.12$ & $2.16 \pm 0.14$ & $2.11 \pm 0.23$ & $2.11 \pm 0.16$ \\
\hline $\mathrm{C} 17: 0$ & $0.21 \pm 0.06$ & $0.23 \pm 0.03$ & $0.20 \pm 0.08$ & $0.22 \pm 0.06$ \\
\hline $\mathrm{C} 17: 1$ & $0.25 \pm 0.06$ & $0.29 \pm 0.04$ & $0.22 \pm 0.09$ & $0.24 \pm 0.07$ \\
\hline C18:0 & $13.68 \pm 0.57$ & $14.25 \pm 0.54$ & $14.32 \pm 0.92$ & $14.47 \pm 0.91$ \\
\hline $\mathrm{C} 18: 1$ trans & $0.31 \pm 0.15$ & $0.33 \pm 0.20$ & $0.32 \pm 0.15$ & $0.24 \pm 0.07$ \\
\hline $\mathrm{C} 18: 1 \mathrm{cis}$ & $40.31 \pm 1.39$ & $41.18 \pm 1.03$ & $39.23 \pm 2.10$ & $39.36 \pm 2.01$ \\
\hline C18:1 n7 & $1.98 \pm 0.78$ & $1.48 \pm 1.32$ & $1.66 \pm 1.23$ & $2.15 \pm 0.84$ \\
\hline C18:2 n6 trans & $0.15 \pm 0.03$ & $0.13 \pm 0.04$ & $0.14 \pm 0.03$ & $0.14 \pm 0.02$ \\
\hline $\mathrm{C} 18: 2 \mathrm{n} 6 \mathrm{cis}$ & $10.02 \pm 1.61$ & $11.29 \pm 1.28$ & $11.11 \pm 2.26$ & $11.55 \pm 1.19$ \\
\hline $\mathrm{C} 18: 3 \mathrm{n} 3$ trans & $0.12 \pm 0.08$ & $0.11 \pm 0.07$ & $0.14 \pm 0.05$ & $0.08 \pm 0.06$ \\
\hline $\mathrm{C} 18: 3 \mathrm{n} 3 \mathrm{cis}$ & $0.44 \pm 0.11$ & $0.58 \pm 0.18$ & $0.58 \pm 0.17$ & $0.55 \pm 0.11$ \\
\hline C20:0 & $0.31 \pm 0.09$ & $0.23 \pm 0.12$ & $0.25 \pm 0.03$ & $0.24 \pm 0.04$ \\
\hline C20:1 & $0.78 \pm 0.26$ & $0.64 \pm 0.15$ & $0.68 \pm 0.13$ & $0.71 \pm 0.17$ \\
\hline $\mathrm{C} 22: 0$ & $0.15 \pm 0.06$ & $0.13 \pm 0.07$ & $0.22 \pm 0.26$ & $0.13 \pm 0.06$ \\
\hline Saturated FA & $43.60 \pm 2.22$ & $42.09 \pm 1.04$ & $43.50 \pm 2.07$ & $42.48 \pm 2.04$ \\
\hline Monounsaturated FA & $46.21 \pm 1.00$ & $46.51 \pm 1.25$ & $44.67 \pm 2.21$ & $45.20 \pm 2.24$ \\
\hline Polyunsaturated FA & $10.74 \pm 1.70$ & $12.11 \pm 1.29$ & $11.96 \pm 2.32$ & $12.32 \pm 1.24$ \\
\hline
\end{tabular}

FA = Fatty acids. Groups: $\mathrm{A}=0 \mathrm{~g}$ carob pods $/ \mathrm{kg}$ feed; $\mathrm{B}=75 \mathrm{~g}$ carob pods $/ \mathrm{kg}$ feed; $\mathrm{C}=100 \mathrm{~g}$ carob pods $/ \mathrm{kg}$ feed; $\mathrm{D}=125 \mathrm{~g}$ carob pods $/ \mathrm{kg}$ feed. Groups did not differ significantly $(\mathrm{p}>0.05)$.

differences were found for the steaks' AS, EE, CP and MO. Also, according to Table 5, no differences $(p>0.05)$ were noticed in the 13 th rib steak fatty acid profile between the four experimental groups.

Moreover, Table 6 presents the result of the regression analysis of the effect of dietary carob pods on the performance and meat quality parameters. A strong tendency $(p=0.056)$ for linear increase was found in the polyunsaturated fatty acids content of the 13 th rib steak. No significant effects $(p>0.05)$ were noticed in the other examined parameters.

\section{DISCUSSION}

The target of the present research was to evaluate the effect of dietary carob pods on growth performance of fattening pigs and their carcass quality, since current information concerning this data is non existent.

The utilization of carobs pods in pig feeding at level of $125 \mathrm{~g} / \mathrm{kg}$ did not have any effect on body weight during the whole experimental period, whereas at levels of $75 \mathrm{~g} / \mathrm{kg}$ and
$100 \mathrm{~g} / \mathrm{kg}$ resulted in significant increase of body weight at slaughter. In previous studies by Lizardo et al. (2002) and Andres-Elias et al. (2007) it was reported that dietary carob did not affect the growth of weaned piglets. Carob pod contain tannins that can act as antinutritional factors, due to their capacity to reduce the digestibility of proteins in the pig rations (Mariscal-Landin et al., 2004). According to Kotrotsios et al. (2010) carob pods inclusion in pig diets significantly reduced the digestibility of proteins, fats, fibers and minerals, especially in the weaning and growing periods. The action of tannins on animals probably depends on their solubility, in the gastrointestinal tract (Tamir and Alumot, 1969; Serrano et al., 2009). Experimental diets at any level had no influence on feed efficiency, results that are in accordance with previous findings in weaned piglets (Lanza et al., 1983).

Carcass yield was not affected by the dietary inclusion of carob pods at any level, compared to controls, while carcass weight was heavier in pigs fed carobs either $75 \mathrm{~g} / \mathrm{kg}$ or $100 \mathrm{~g} / \mathrm{kg}$. This finding is probably the result of the increased body weight of the pigs. 
Table 6. Regression analysis of the effect of dietary carob pods on pig performance and meat quality parameters

\begin{tabular}{|c|c|c|c|c|}
\hline Parameter & $\mathrm{P}$ & $\mathrm{R}^{2}$ & A & $\mathrm{B}$ \\
\hline Body weight at d $85(\mathrm{~kg})$ & 0.791 & 0.000 & 28.777 & 0.003 \\
\hline Body weight at d $115(\mathrm{~kg})$ & 0.842 & 0.000 & 51.009 & 0.004 \\
\hline Body weight at d $180(\mathrm{~kg})$ & 0.574 & 0.002 & 112.419 & -0.013 \\
\hline Carcass weight (kg) & 0.566 & 0.002 & 67.832 & -0.009 \\
\hline Carcass dressing (\%) & 0.729 & 0.001 & 60.412 & -0.002 \\
\hline Subcutaneous fat of 13th rib (mm) & 0.487 & 0.016 & 17.038 & -0.009 \\
\hline Subcutaneous fat of 6th to 7th lumbar vertebrae (mm) & 0.263 & 0.041 & 24.067 & -0.020 \\
\hline Steak ash $(\mathrm{g} / \mathrm{kg})$ & 0.149 & 0.068 & 0.887 & 0.000 \\
\hline Steak ether extract $(\mathrm{g} / \mathrm{kg})$ & 0.206 & 0.053 & 15.576 & -0.028 \\
\hline Steak crude protein $(\mathrm{g} / \mathrm{kg})$ & 0.590 & 0.010 & 20.074 & 0.007 \\
\hline Steak moisture (g/kg) & 0.168 & 0.062 & 63.481 & 0.021 \\
\hline Steak saturated FA $(\%)$ & 0.361 & 0.028 & 43.375 & -0.007 \\
\hline Steak monounsaturated FA (\%) & 0.146 & 0.069 & 46.413 & -0.010 \\
\hline Steak polyunsaturated FA (\%) & 0.056 & 0.117 & 10.822 & 0.012 \\
\hline
\end{tabular}

Regression equation: Parameter $=\mathrm{A}+\mathrm{B} \times \mathrm{Carob}$ pod addition in feed $(\mathrm{g} / \mathrm{kg})$. Steak $=$ Steak of the 13 th rib; FA $=$ Fatty acids.

Carob pods had no significant effect on examined meat quality, since neither lard thickness nor chemical composition and fatty acid profile of the pig steaks were influenced. Nevertheless, it was noticed that increased inclusion rates of dietary carob pods resulted in a tendency for increased polyunsaturated fatty acid content in the steak.

In conclusion, from the present study it is evident that the inclusion of carob pods in fattening pig diets, at the level of $75 \mathrm{~g} / \mathrm{kg}$ and $100 \mathrm{~g} / \mathrm{kg}$ improved body weight and carcass weight. Moreover, carob pods at any examined level had no influence on the meat quality of pigs, including lard thickness, chemical composition and fatty acid profile of the steak. Consequently, carob pods could be suggested as a potential feed for fattening pigs.

\section{REFERENCES}

Albanell, E., G. Caja and J. Plaixats. 1991. Characteristics of Spanish carob pods and nutritive value of carob kibbles. Options Mediterraneennes - Serie Seminaries. 16:135-136.

Andres-Elias, N., J. Pujols, I. Badiola and D. Torrallardona. 2007. Effect of nucleotides and carob pulp on gut health and performance of weanling piglets. Livest. Sci. 108:280-283.

AOAC. 2005. Official methods of analysis. 18th edition. Association of Analytical Chemists, AOAC International, Arlington Virginia, USA.

Barracosa, P., J. Osorio and A. Cravador. 2007. Evaluation of fruit and seed diversity and characterization of carob (Ceratonia siliqua L.) cultivars in Algarve region. Sci. Hortic. 114:250257.

Biagi, G., I. Cipollini, B. R. Paulicks and F. X. Roth. 2010. Effect of tannins on growth performance and intestinal ecosystem in weaned piglets. Arch. Anim. Nutr. 64:121-135.

Custodio, L., E. Fernandes, A. L. Escapa, A. Fajardo, R. Aligue, F. Albericio, N. R. Neng, J. M. F. Nogueira and A. Romano. 2011.
Antioxidant and cytotoxic activities of carob tree fruit pulps are strongly influenced by gender and cultivar. J. Agric. Food Chem. 59:7005-7012.

FAO. 2009. FAOSTAT final data. http://faostat.fao.org/site/567/ DesktopDefault.aspx? PageID $=567 \#$ ancor .

Gasmi-Boubaker, A., R. Bergaoui, A. Khaldi, M. R. MosqueraLosada and A. Ketata. 2008. First attempt to study carob pulp utilization in rabbit feeding. World J. Agric. Sci. 4:67-70.

Karabulut, A., O. Canbolat and A. Kamalak. 2006. Evaluation of carob, Ceratonia siliqua pods as a feed for sheep. Livest. Res. Rural Dev. 18(7).

Kotrotsios, N., E. V. Christaki, E. M. Bonos and P. C. FlorouPaneri. 2010. The effect of dietary carob pods on nutrient digestibility in weaning, growing and fattening periods of pigs. J. Food Agric. Environ. 8:779-782.

Lanza, A., G. D' Urso, E. Lanza and C. Aleo. 1983. Esperienze d'impiego di un semolato di carruba ad umidita in diete per suini. Tec. Agric. 35:115-127.

Lizardo, R., J. Canellas, F. Mas, D. Torrallardona and J. Brufau. 2002. Utilisation of carob powder in piglet diets and its influence on growth performance and health after weaning. 34emes Journees de la Recherche Porcine, sous l'egide de 1' Association Franccaise de Zootechnie, Paris, France, 5-7 Fevrier.

Makkar, H. P. S. 2003. Quantification of tannins in tree and shrub foliage. A laboratory manual. Kluwer Academic Publishers, UK.

Mariscal-Landin, G., J. H. Avellaneda, T. C. Reis de Souza, A. Aguilera, G. A. Borbolla and B. Mar. 2004. Effect of tannins in sorghum on amino acid ileal digestibility and on trypsin (E.C.2.4.21.4) and chymotrypsin (E.C.2.4.21.1) activity of growing pigs. Anim. Feed Sci. Technol. 117:245-264.

Mohamed, D. A., I. M. Hamed and S. Y. Al-Okbi. 2008. Ceratonia siliqua pods as a cheap source of functional food components. Dtsch. Lebensmitt. Rundsch. 104:25-29.

NRC. 1998. Nutrient requirements of swine. 10th Revised Edition. National Research Council, National Academy Press, 
Washington, DC, USA.

Ortiz, L. T., M. L. Rodriguez, C. Alzueta, A. Rebole, C. Centeno and J. Trevino. 2004. Effect of carob seed (Ceratonia Siliqua L.) in broiler chick diets on nutrient digestibility and intestinal viscosity. In: EAAP Publication 110, Spain. pp. 239-242.

Porter, J. L. 1989. Tannins. In: Methods in Plant Biochemistry (Ed. J. B. Harborne and P. M. Dey). Academic Press, London, UK. pp. 389-419.

Priolo, A., M. Lanza, L. Biondi, P. Pappalardo and O. A. Young. 1998. Effect of partially replacing dietary barley with $20 \%$ carob pulp on post-weaning growth, and carcass and meat characteristics of Comisana lamb. Meat Sci. 50:355-363.

Sahle, M., J. Coleou and C. Haas. 1992. Carob pod (Ceratonia siliqua) meal in geese diets. Br. Poult. Sci. 33:531-541.
Serrano, J., R. Puupponen-Pimia, A. Dauer, A. Aura and F. SauraCalixto. 2009. Tannins: Current knowledge of food, sources, intake, bioavailability and biological effects. Mol. Nutr. Food Res. 53:S310-S329.

Silanikove, N., S. Landau, D. Or, D. Kababya, I. Bruckental and Z. Nitsan. 2006. Analytical approach and effects of condensed tannins in carob pods (Ceratonia siliqua) on feed intake, digestive and metabolic responses of kids. Livest. Sci. 99:2938.

Tamir, M. and E. Alumot. 1969. Carob tannins - growth depression and levels of insoluble nitrogen in the digestive tract of rats. J. Nutr. 100:573-580.

Tous, J., A. Romero, J. F. Hermoso, A. Ninot, J. Plana and I. Batlle. 2009. Agronomic and commercial performance of four Spanish carob cultivars. HortTechnology 19:465-470. 